\title{
Study on the countermeasures of Xi 'an eco - city development from the perspective of green development
}

\author{
Yang Wenxuan ${ }^{1, a}$, Kang Jiaxin ${ }^{2, b^{*}}$ \\ ${ }^{1}$ Xi'an University of Technology, xi'an, shaan xi, China \\ ${ }^{2}$ Xi'an University of Technology, xi'an, shaan xi, China \\ a657803827@qq.com,b403374836@qq.com
}

\begin{abstract}
Keywords: Eco-friendly development, Development of ecological city in Xi 'an, Countermeasure
\end{abstract} research.

\begin{abstract}
The concept of ecological city is a reflection on the original urban construction mode and development mode. Based on the summary of $\mathrm{Xi}$ 'an eco-city construction resources, this paper analyzes the present situation of $\mathrm{Xi}$ 'an eco-city construction. aiming at the problems of eco-city development mode with eco-tourism as the core, eco-city construction should uphold the concept and consciousness, eco-city planning is insufficient, the level of eco-environmental protection is low, the countermeasures and suggestions of $\mathrm{Xi}$ 'an eco-city construction are formulated from six aspects.
\end{abstract}

\section{绿色发展视角下西安生态城市发展对策研究 \\ 杨文选 1 , a 穴佳欣 2, b * \\ 1西安理工大学马克思主义学院, 西安, 陕西, 中国 \\ 2西安理工大学马克思主义学院, 西安, 陕西, 中国 \\ a 657803827@qq.com, b403374836@qq.com}

关键词: 绿色发展; 西安生态城市发展; 对策研究

中文摘要. 生态城市理念是对原有城市建设模式和发展方式的一种反思。本文对西安生态城 市建设资源综述基础上, 分析了西安生态城市建设现状, 针对生态城市发展模式以生态旅游 为核心、生态城市建设应秉持的理念与意识欠缺、生态城市规划不足、生态环境保护水平较 低等问题，从六个方面制定了西安构建生态城市的对策和建议。

\section{1. 引言}

十九大报告指出要创造更多物质财富和精神财富以满足人民日益增长的美好生活需要， 也要提供更多优质生态产品以满足人民日益增长的优美生态环境需要, 即把保护生态环境的 重要性上升到前所未有的高度。西安市位于陕西省中部的关中平原地区, 地势较周边地区低, 年均气温相对陕西省整体来说较高, 毗邻秦岭, 周边水资源丰富, 有 “八水绕长安” 的美称, 不仅满足人民用水需求，也形成良好的自然生态景观。此外，西安市作为历史文化名城，拥 有众多文物遗迹，自然景观与人文建筑的交相辉映构成了独特的生态格局。在此背景下，建 设西安生态城市不仅要重视自然环境的建设, 也要重视文化遗产的保护，使水资源得到合理 保护与开发，使历史遗迹绽放古城魅力，形成具有西安特色的生态城市。 


\section{2. 西安生态城市构建现状与问题}

\section{1 生态城市发展模式以生态旅游为核心}

对生态城市发展模式的研究, 学术界形成生态旅游型、海滨型、森林型和节水型等四种 类型, 各城市根据自身实际情况选用。西安市依托良好的自然生态环境, 选择生态旅游型城 市发展模式。

西安市旅游资源丰富, 城市周边山林环绕, 城市内部生态景观建设与城市发展相得益彰, 由统计数据可知，西安市2017年旅游业对全市生产总值的贡献率达到四分之一，对经济良性 发展做出巨大贡献。西安市历来注重旅游业的发展, 大力投资生态园区建设, 形成浐灞生态 区及草滩自然旅游区, 此外, 西安周边县区的旅游产业发展势头强劲, 依托良好的秦岭生态 环境，建设沿线旅游观光区，带动农家乐、森林公园、生态古镇等多项产业发展。在开发利 用生态资源的同时，西安市注重对生态环境的保护，使开发利用和修复保护相结合，达到经 济增长和生态环境的协调发展。

\section{2 生态城市建设应秉持的理念与意识欠缺}

西安是历史文化名城，拥有丰富的历史文化资源，源远流长的传统文化积淀形成了独特 的文化氛围和民族特性，大多数西安市民都有安贫乐道、知足常乐的生活态度，使得西安人 乐观向上的品格特点得到传承，但也正是由于传统思想的长期积累，使得西安人思想过于保 守, 创新能力较为滞后, 面对新时代城市建设中存在的问题, 往往不能用发展的眼光看问题。

\section{3 生态城市规划不足}

（1）城市建设与生态治理矛盾。西安属于西北内陆地区，与内陆其他城市相比，西安经济 发展速度较快, 但与东部发达地区相比, 西安市经济发展模式和发展质量还需进一步转变。 在城市扩张过程中，不可避免的会造成资源能源的消耗，使得城市建设的推进带来生态环境 的持续恶化问题逐渐凸显。

(2) 忽视社会公众参与作用。政府部门的城市建设理念落后, 一味强调政府在城市建设中 的主导地位, 没有意识到社会公众作为城市生活主体所具有的话语权和主观能动性, 这会造 成城市建设脱离现实依据，导致政府部门工作不到位、效率不高的问题。

\section{4 生态环境保护水平较低}

（1）环境指数严重超标。长期以来, 为了提升就业率, 保障日益增长的城市人口的正常生 活, 西安市将大部分精力放在如何发展经济上, 高速发展的理念始终占据主导地位, 在近 10 年间, 西安市生产总值长期保持 $10 \%$ 以上的发展速度，人民物质生活得到有效提升，但经济的 快速发展也造成严重的生态环境问题，水质污染、雾霾问题频现，多项环境指标超标，如表1 所示。

表 1 西安市主要环境指标与生态城市指标要求

\begin{tabular}{cccc}
\hline 指标名称 & 单位 & 生态城市指标 & 西安市现状 \\
\hline 单位GDP能耗 & 吨标煤 & $\leqq 1.4$ & 0.934 \\
森林覆盖率 (平原) & $\%$ & $\geqq 15$ & 12 \\
城市空气质量 & 2级标准的天数/年 & $\geqq 280$ & 289 \\
二氧化硫排放强度 & $\mathrm{Kg} /$ 万元 $(\mathrm{GDP})$ & $\leqq 5.0$ & 102 \\
城镇生活污水集中处理率 & $\%$ & $\geqq 70$ & 40.6 \\
噪声达标区覆盖率 & $\%$ & $\geqq 95$ & 60.21 \\
人均公共绿地面积 & $\%$ & $\geqq 11$ & 7.9 \\
\hline
\end{tabular}

数据来源：西安市环境保护研究所统计资料；西安市统计年鉴（2017） 
（2）建成区面积不断扩大。相关统计资料表明，西安市2000-2017年城市建成区面积由 $187 \mathrm{~km}^{2}$ 增长到 $432 \mathrm{~km}^{2}$, 面积增加了一倍多, 为了追求利益最大化, 在城市建设过程中会减少 园林绿地耕地的面积, 形成了 “摊大饼式” 的城市发展模式。西安市2001-2017年人均公共绿 地面积由 $5.12 \mathrm{~m}^{2}$ 增长 $9.60 \mathrm{~m}^{2}$, 增长速度十分缓慢, 而全国平均人均公用绿地水平值为 $30.62 \mathrm{~m}^{2}$, 全国生态城市的最低人均公共绿地面积指标最低为 $11 \mathrm{~m}^{2}$, 西安市的人均公共绿地面积水平仍 然具有较大的提升空间。

\section{3. 西安生态城市构建策略}

西安在生态城市建设过程中, 应当以自身的特点和条件为基础, 结合实际发展状况, 积 极探索相应的发展策略。

\section{1 城市功能布局生态化}

创建 “一城多心” 的发展模式, 优化城市功能布局, 在城市发展的过程中要注重对生态 环境、有价值的历史文化遗址和耕地的保护，合理规划城乡发展，利用林草绿地等把主要的 人口聚集区链接起来, 形成一个绿色的生态系统。对老城区功能进行重新疏导, 以市区为核 心，同时完善周边各区县的城市功能，建立一体化的城市发展网络系统。

\section{2 城市产业生态化}

积极发展低碳经济，加快节能环保新技术、新设备和新产品的研发和推广速度，重点推 进固体废弃物处理、水体污染和空气污染治理、生态环境监测仪器等技术的发展, 加大可再 生能源和清洁能源的使用力度。在工业发展的过程中, 坚持生态发展理念, 创建 “环境友好 型” 企业。发展生态农业, 加快推进河道、耕地、水域和道路等基础设施建设, 配套完善综 合服务功能，实现农业园区化和基地化，打造农业循环经济发展模式。倡导使用农家肥和有 机肥，大力推行农作物病虫害绿色防控技术，严格限制剧毒、高毒、高残留农药和肥料的使 用。优化经济发展结构, 提高第三产业的比重, 重点发展旅游、商贸、会展、金融等绿色产 业。

\section{3 城乡居民生活空间生态化}

扩大城乡居民居住区的绿地面积, 提高林草覆盖率, 种植的树木要与本地的气候条件相 适应, 建设生态化文化广场, 实现社区绿色化、园林化, 同时应当尽量使用水泥对路面进行 硬化, 努力提高居民的生活环境质量。对市区的绿地、园林和建筑进行科学的规划和合理的 布局, 积极推广垂直绿化和屋顶绿化的实施, 加快绿色建筑的发展。

\section{4 城乡居民观念行为生态化}

加大环境保护的宣传力度，提升居民的生态环境保护意识，牢固树立人与自然和谐相处 的价值观念, 用严格的法律制度对生态环境进行保护，对人们在吃、行、穿、用、住等方面 的行为进行规范，引导消费者转向绿色消费，使爱护生态环境的观念深入人心。

\section{5 创建节水节能型社会}

对水资源推行严格的统一化管理体制, 提升中水的使用效率, 对其总量进行有效的控制, 建立市场化运作机制。农业用水应当发展喷灌、滴灌等节水灌溉技术，避免水资源的浪费; 对于耗水量较高的工业企业, 应当对其进行整改或者直接淘汰, 大力推广高效的节水设备和 工艺; 通过调整水价、推广节水型器具的方式, 帮助市民树立节约用水的意识, 以减少对生 活用水的浪费。建立节约用水试点, 通过对节约用水的宣传带动市民对电、气等生活能源的 节约, 加大对节能环保产品和器具的推广力度, 倡导绿色环保的生活方式, 建设资源节约型、 环境友好型社会。 


\section{6 积极倡导生态旅游}

在城市经济转型发展的今天, 旅游业在国民经济中的地位日益重要, 成为推动社会经济 发展的重要因素。旅游业在推动经济发展的同时, 也带来了严重的污染问题, 所以在发展绿 色经济的同时应当构建生态旅游的发展模式。

\section{Acknowledgment}

This article is one of the periodical research results of the modern governance research of Shaanxi's industrial green development (2018JD010).

\section{References}

[1] Guo Yajun, Pan Jianmin, Building a green city is a strategic choice for sustainable development, Economic research data, vol.07, pp. 25-27, 2001.

[2] Xu Gaihua, Study on dynamic characteristics of urban land use change and built - up area expansion, Shaanxi normal university,2012.

[3] Han Zhuo, Analysis on the present situation and strategy of Xi 'an eco - city development, Journal of Anhui Agricultural University, vol.02, pp. 30-34, 2014.

[4] Feng Ying, Thinking and mode selection of ecological city construction in Xi 'an, Modern Economic Information, vol. 04, pp. 24-26, 2015.

[5] Tian Huaxian, Study on the construction path of Xi 'an ecological city, Xi'an University Of Architecture And Technology, 2013.

[6] Li Qi, Cao Kaining, LiuYongXiang, The construction goal and strategy of Xi 'an ecological city, Planners, vol. 01, pp. 101-105, 2014. 